\title{
Gastroprotective effect of Byrsonima sericea DC leaf extract against ethanol-induced gastric injury and its possible mechanisms of action
}

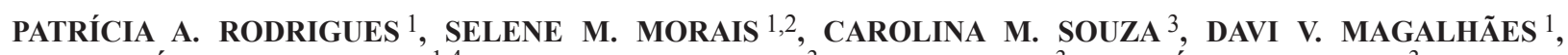 \\ ÍCARO G.P. VIEIRA ${ }^{1,4}$, GEANNE M. ANDRADE ${ }^{3}$, VIETLA S. RAO ${ }^{3}$ and FLÁVIA A. SANTOS ${ }^{3}$ \\ ${ }^{1}$ Programa de Pós-Graduação em Ciências Veterinárias, Faculdade de Veterinária, Universidade Estadual do Ceará, \\ Av. Paranjana, 1700, Campus do Itaperi, 60740-000 Fortaleza CE, Brasil \\ ${ }^{2}$ Departamento de Química, Laboratório de Química de Produtos Naturais, Universidade Estadual do Ceará, \\ Av. Paranjana, 1700, Campus do Itaperi, 60740-000 Fortaleza, CE, Brasil \\ ${ }^{3}$ Departamento de Fisiologia e Farmacologia, Universidade Federal do Ceará, Faculdade de Medicina, \\ Rua Coronel Nunes de Melo, 127, Rodolfo Teófilo, 60430-270 Fortaleza, CE, Brasil \\ 4 PADETEC-Parque de Desenvolvimento Tecnológico, Universidade Federal do Ceará, \\ Av. Humberto Monte, 2977, Bairro Parquelândia, Bloco 310, 60.440-593 Fortaleza, CE, Brasil.
}

Manuscript received on October 7, 2010; accepted for publication on March 1, 2011

\begin{abstract}
Byrsonima sericea leaves are extensively used in folk medicine in Brazil against gastric disorders. This study investigated the chemical constituents of $B$. sericea leaf ethanolic extract (BSLE) and its potential gastroprotective activity, with its possible mechanism of the action using ethanol to induce gastric mucosal damage in mice. The phytochemical analysis was carried out to identify the active constituents present in the extract, and the HPLC analysis was performed for the identification of flavonoids. BSLE at oral doses of 125,250 and $500 \mathrm{mg} / \mathrm{kg}$ markedly attenuated the ethanol-evoked gastric lesions by 53.2 , 84.9 and $87.6 \%$, respectively. The BSLE $(250 \mathrm{mg} / \mathrm{kg})$ prevented the depletion of gastric mucus and gastric mucosal nonproteic-sulfhydryl groups, SOD and CAT, as well as the increase in the MDA content promoted by absolute ethanol. Moreover, the effect of BSLE against ethanol damage was found to be significantly reduced in mice pretreated with Capsazepine (i.p.), L-NAME (i.p.) or glibenclamide (i.p.), the respective blockers/inhibitors of TRPV1, NO synthase and K+ATP channel. The phytochemical investigation on BSLE revealed the presence of flavonoids rutin, isoquercitrin, kaempferol 3-O-rutinoside and quercetin, which are compounds well known for their antioxidant and gastroprotective properties. These results suggest that BSLE affords gastroprotection through multiple mechanisms, which may be helpful in the treatment of pathologies associated with gastric dysfunctions.
\end{abstract}

Key words: antioxidant, Byrsonima sericea, flavonoids, gastroprotection, mechanisms of action.

\section{INTRODUCTION}

Plants of the genus Byrsonima (Malpighiaceae) are widely distributed in various parts of Brazil where local people call them murici. Leaves and trunk barks from various species the Byrsonima are

Correspondence to: Selene Maia de Morais

E-mail: selenemaiademorais@gmail.com popularly employed in folk medicine to treat fever, gastrointestinal dysfunction (diarrhea and gastric ulcer), asthma, skin infections, and snakebites (Lira et al. 2008, Mendes et al. 1999). While chemical investigations on various Byrsonima species have shown the presence of several bioactive compounds like flavonoids, triterpenes and tannins (Mendes et 
al. 1999, Martínez-Vázquez et al. 1999), bioactivity studies have demonstrated the gastroprotective, healing and antidiarrheal activities of B. fagifolia (Lima et al. 2008), the antimutagenic activity of B. basiloba (Lira et al. 2008), and the mutagenic and gastroprotective effects of Byrsonima crassa (Cardoso et al. 2006, Sannomiya et al. 2007).

The presence of phenolic compounds possibly explains the gastroprotective effect of the extracts of Byrsonima species. Byrsonima sericea DC (Fig. 1) grows abundantly in the Northeastern states of Brazil, and it is traditionally used to treat gastrointestinal dysfunction. An antioxidant activity of the methanol extract from $B$. sericea has recently been described, using the DPPH assay (Boscolo et al. 2007).

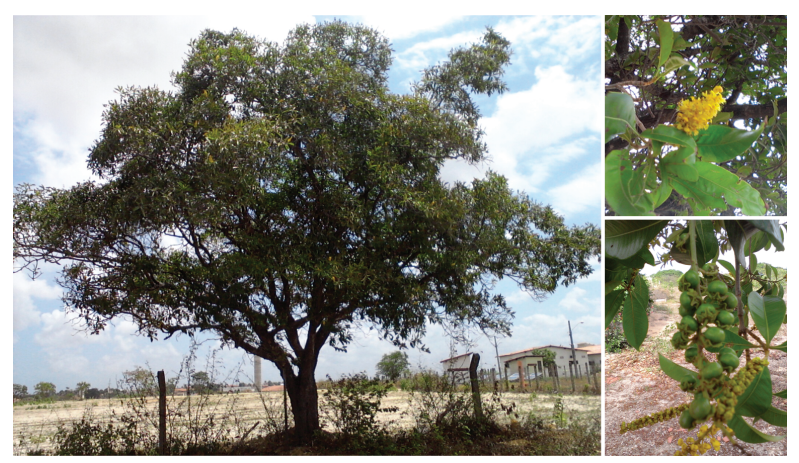

Fig. 1 - View of fruits and flowers and an adult individual of Byrsonima sericea (by Pablito Augusto Travassos Ferreira) .

To our knowledge, there were no scientific studies in literature on $B$. sericea extracts in relation to the regarding its gastrointestinal activity. Since antioxidants can afford gastroprotection both in clinical and experimental settings, the present study aimed at evaluating the $B$. sericea leaf extract (BSLE) for potential gastroprotection and its underlying mechanism of the action using the ethanol to induce gastric damage in mice as a model system. In addition, the phytochemical analysis of the extract was carried out to identify the chemical compounds that were probably responsible for protecting the plants.

\section{MATERIALS AND METHODS}

Chemicals

Capsaicin, capsazepine, glibenclamide, diazoxide, L-arginine and L-NAME were purchased from Sigma Chemical Co. (St Louis, MO, USA). Absolute ethanol was obtained from Synth (Brazil). All other chemicals used were of analytical grade. Quercetin, quercetin 3-O-glycoside (isoquercetin), quercetin 3-O-rutinoside (rutin) and kaempferol 3-O-rutinoside isolated from the flowers and leaves of Dimophandra gardneriana, were used as standards.

PLANT MATERIAL AND EXTRACT PREPARATION

B. sericea leaves were collected from the State University of Ceará campus, Ceará State, Brazil, in April 2008, after their identification by Dr. Afrânio G. Fernandes, botanist of the Federal University of Ceará. A voucher specimen (\#39.451) has been deposited at Prisco Bezerra Herbarium. Fresh leaves $(1.24 \mathrm{~kg})$ were macerated with $70 \%$ ethanol at room temperature for 7 days. The resultant ethanolic solution was filtered with filter paper using a buchner funnel under vacuum and evaporated to dryness at $50^{\circ} \mathrm{C}$ in a rotary evaporator to yield $153 \mathrm{~g}$ of crude ethanolic extract. This extract was then submitted to a chromatographic treatment process using silica gel column being eluted with solvents hexane, ethyl acetate and ethanol. With the evaporation of these solvents, the three correspondent extracts weighed 1.1, 5.6 and $126.2 \mathrm{~g}$ respectively. Only the ethanolic extract (BSLE) was utilized in the present work.

PHytochemical ANALYsis

BSLE was analyzed for the presence of phenols, tannins, leucoantocianidins, flavonoids, steroids, triterpenes and alkaloids by the qualitative chemical analysis (Matos 1997) 


\section{HPLC ANALYSIS}

The HPLC system (Waters 2690 Alliance) was connected to a Waters 486 tunable absorbance, column detector (Waters C18, 3.9 X 150mm X 4um). The analysis was run under isocratic conditions using the solvent mixture: 80:20 ( $\mathrm{ACN}: \mathrm{H}_{2} \mathrm{O}, \mathrm{pH} 2.8$ phosphoric acid), flow rate: $1 \mathrm{~mL} / \mathrm{min}, 20 \mu \mathrm{L}$; and temperature: $21^{\circ} \mathrm{C}$. The concentrations of extract and standards were $1 \mathrm{mg} / \mathrm{mL}$, the injection volume was $30 \mu \mathrm{L}$ and the eluted was monitored at $350 \mathrm{~nm}$.

\section{ANIMALS}

Female Swiss mice (20-25 g) obtained from the Central Animal House of this university were used. Experimental groups consisted of 8 animals per group. They were housed at $24 \pm 2^{\circ} \mathrm{C}$ under a 12-h light/12-h dark cycle and had free access to standard pellet diet (Purina chow) and tap water. The animals were deprived of food for $15 \mathrm{~h}$ before the experimentation, but had free access to drinking water. The Institutional Ethics Committee on the Care and Use of Animals for experimentation approved the experimental protocols ( $\mathrm{N}^{\mathrm{o}}$ 07520831-8), and all experiments were performed in accordance with the guidelines of the National Institute of Health, Bethesda, USA.

\section{GASTRIC DAMAGE INDUCED BY ETHANOL}

Groups of mice $(n=8)$, were pre-treated with the vehicle $(0.5 \%$ of DMSO in saline, $10 \mathrm{~mL} / \mathrm{kg})$, $\mathrm{N}$-acetylcysteine (NAC, $150 \mathrm{mg} / \mathrm{kg}$, i.p.) or BSLE $(125,250$ and $500 \mathrm{mg} / \mathrm{kg}$, v.o.) one hour before the induction of gastric damage by oral administration of absolute ethanol (96\%, $0.2 \mathrm{~mL} / \mathrm{animal})$ (Robert et al. 1979). After $30 \mathrm{~min}$ the animals were sacrificed and their stomachs excised, opened along the greater curvature and rinsed with saline $(0.9 \%)$. The mucosal lesion area $\left(\mathrm{mm}^{2}\right)$ was measured by planimetry using a transparent grid (area: $1 \mathrm{~mm}^{2}$ ) placed on the glandular mucosal surface and expressed in percentage (\%) in relation to the total area of the corpus. After the evaluation of the lesions induced by ethanol, the glandular parts of the stomachs were frozen and stored at $-70{ }^{\circ} \mathrm{C}$ for further biochemical analyses.

\section{DETERMINATION OF GASTRIC MUCUS}

Gastric mucus content was measured according to the methodology described by Corne et al. (1974). The gastric tissues were transferred to $0.1 \%$ Alcian Blue solution prepared in $16 \mathrm{mM}$ sucrose and $50 \mathrm{mM}$ sodium acetate $(\mathrm{pH} 5.8)$ and kept for $2 \mathrm{~h}$ at room temperature. The segments were then rinsed twice with $25 \mathrm{mM}$ sucrose solution for 15 and $45 \mathrm{~min}$, and the dye solution, together with the gastric mucus with $5 \mathrm{mM}$ of magnesium chloride solution, was extracted for $2 \mathrm{~h}$. The extract was then mixed with an equal volume of diethyl ether and centrifuged (1000g) for $10 \mathrm{~min}$. The absorbance was determined at $598 \mathrm{~nm}$. The amount of mucus was calculated using a standard curve of Alcian Blue.

\section{ESTIMATION OF ANTI-OXIDANT PARAMETERS}

Gastric strips were cut into small pieces and then homogenized in ice-cold $50 \mathrm{mM}$ Phosphate buffer $\mathrm{pH} 7.4$ to obtain a $10 \%$ homogenate. The homogenate was then made into aliquots and used for the assessment of anti-oxidant parameters.

\section{DETERMINATION OF NONPROTEIC}

SULFHYDRYL GROUPS (NP-SH)

NP-SH was determined according to the method described by Sedlak and Lindsay (1968). Aliquots (2 $\mathrm{mL}$ ) of $10 \%$ tissue homogenate were mixed with $1.6 \mathrm{~mL}$ of distilled water and $0.4 \mathrm{~mL}$ of trichloroacetic acid (TCA) 50\% (w/v) and then centrifuged at $3000 \mathrm{~g}$ for $15 \mathrm{~min}$. The supernatants 
( $2 \mathrm{~mL}$ ) were then mixed with $4 \mathrm{~mL}$ of tris buffer (40 mM, pH 8.9), and 5,5'-ditiobis (2-nitrobenzoic acid) (DTNB, $10 \mathrm{mM}$ ) was added. The absorbance was measured within 5 min after the addition of DTNB at $412 \mathrm{~nm}$ against a reagent blank with no homogenate. The absorbance values were extrapolated from a glutathione standard curve and expressed as $\mu \mathrm{g} / \mathrm{g}$ of stomach tissue.

SUPEROXIDE DISMUTASE (SOD) ACTIVITY

The SOD activity was assessed through the measurement of the enzyme capacity for the photochemical inhibition of nitroblue-tetrazolium (NBT) (Beauchamp and Fridovich 1971). The reduction of NBT by $\mathrm{O}_{2}^{-}$was utilized as the basis of assays for superoxide dismutase, which shows its presence by inhibiting the reduction of NBT and producing formazan that is absorbed at $560 \mathrm{~nm}$. Aliquots of tissue homogenates were centrifuged $12,000 \mathrm{~g}$ for $20 \mathrm{~min}$. In a dark room $40 \mu \mathrm{l}$ of phosphate buffer or supernatants were added to glass test tubes containing $1 \mathrm{~mL}$ of reaction mixture (Phosphate buffer $50 \mathrm{mM}$, EDTA $100 \mathrm{nM}$ and L-methionine $19.5 \mu \mathrm{M}$ pH 7.8). Then $150 \mu \mathrm{L}$ of NBT $750 \mu \mathrm{M}$ and $300 \mu \mathrm{L}$ riboflavin $10 \mu \mathrm{M}$ were added. After shacking, the tubes were exposed to light (20 Watt) for $15 \mathrm{~min}$. The absorbance was measured at $560 \mathrm{~nm}$. The results were expressed in enzyme units, which represent the amount of SOD necessary to inhibit the NBT reduction by $50 \%$. The enzymatic activity was expressed as $\mathrm{U} / \mu \mathrm{g}$ of protein.

\section{DETERMINATION OF CATAlase (CAT) ACTIVITY}

The CAT activity was measured by the method that employs hydrogen peroxide to generate $\mathrm{H} 2 \mathrm{O}$ and O2 (Maehly and Chance 1954). The activity was measured by the degree of this reaction. In short, the supernatant $(20 \mu \mathrm{L})$ was added to a quartz cuvette containing $980 \mu \mathrm{L}$ of $\mathrm{H}_{2} \mathrm{O}_{2} 800 \mu \mathrm{M}$, EDTA
$25 \mu \mathrm{M}$ and tris buffer $\mathrm{HCl}(50 \mathrm{mM}, \mathrm{pH} 8.0)$. The change in absorbance was monitored at $240 \mathrm{~nm}$ over a 6-min period using a spectrophotometer. The CAT activity was expressed as $\mathrm{U} / \mu \mathrm{g}$ of protein.

\section{Determination Protein CONTENT}

The protein concentration was determined by the method of Bradford 1976, using bovine serum albumin as a standard.

Determination of Total Thiobarbituric ACID-Reactive SUBSTANCES (TBARS)

Total thiobarbituric acid-reactive substances (TBARS) was determined according to the method of Ohkawa et al. (1979). Gastric strips were cut into small pieces and then homogenized in ice-cold phosphate buffer $(50 \mathrm{mM} \mathrm{pH} 7.4)$ to give a $10 \%$ homogenate. The homogenates were transferred to test tubes and incubated in a water bath at $37^{\circ} \mathrm{C}$ for $60 \mathrm{~min}$. After this period, $35 \%$ of perchloric acid was added. The mixture was centrifuged at $15000 \mathrm{~g}$ for $10 \mathrm{~min}$. Thiobarbituric acid at $0.6 \%$ was then added to the upper layer. The mixture was submitted to a water bath at $100^{\circ} \mathrm{C}$ for $30 \mathrm{~min}$, after which the absorbance was measured at $532 \mathrm{~nm}$. The standard curve was obtained using several concentrations of MDA solutions, expressed in $\mathrm{nmol} / \mathrm{g}$ of wet tissue.

\section{ROLE OF TRPV1 CHANNEL IN THE}

\section{GASTROPROTECTIVE EFFECT OF BSLE}

Groups of mice $(n=8)$ were pretreated with vehicle $(0.9 \%$ saline in a $0.5 \%$ of DMSO, $10 \mathrm{~mL} / \mathrm{kg})$, BSLE $(250 \mathrm{mg} / \mathrm{kg}$, v.o. $)$ and capsaicin $(0.3 \mathrm{mg} / \mathrm{kg}$, v.o. $)$, alone or in their combinations with capsazepine $(5 \mathrm{mg} / \mathrm{kg}$, i.p.) prior to the oral administration of $0.2 \mathrm{ml}$ of ethanol (96\%). When given alone, BSLE and capsaicin were administered $1 \mathrm{~h}$ before the ethanol. Capsazepine was administered $30 \mathrm{~min}$ prior to ethanol. 
ROLE OF NITRIC OXIDE IN THE GASTROPROTECTIVE

EFFECT OF BSLE

Mice ( $\mathrm{n}=8 /$ per group) were pretreated with vehicle $(0.9 \%$ saline in a $0.5 \%$ of DMSO, $10 \mathrm{~mL} / \mathrm{kg})$, BSLE $(250 \mathrm{mg} / \mathrm{kg}$, v.o.) and L-arginine $(600 \mathrm{mg} /$ $\mathrm{kg}$, i.p.), alone or in their combinations with L-NAME $(20 \mathrm{mg} / \mathrm{kg}$, i.p.) prior to the induction of gastric damage with ethanol $(0.2 \mathrm{ml}$ of ethanol, 96\%). While BSLE was administered $1 \mathrm{~h}$ before, L-NAME and L-arginine were given 30 min prior to ethanol (Arrieta et al. 2003).

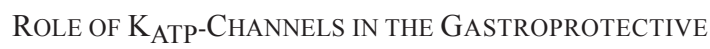
EFFECT OF BSLE

Mice ( $\mathrm{n}=8 /$ per group) were pretreated with vehicle $(0.9 \%$ saline in a $0.5 \%$ of DMSO, $10 \mathrm{~mL} / \mathrm{kg})$, BSLE (250 mg/kg, v.o.) diazoxide (3 mg/kg, i.p.), alone or in their combinations with glibenclamide $(5 \mathrm{mg} /$ $\mathrm{kg}$, i.p.) prior to the oral administration of $0.2 \mathrm{ml}$ of ethanol (96\%). BSLE was given $1 \mathrm{~h}$ before, whereas diazoxide was administered $30 \mathrm{~min}$ prior to ethanol or glibenclamide. Glibenclamide was administered 30 min before BSLE (Peskar et al. 2002).

\section{STATISTICAL ANALYSIS}

The results are presented as the mean \pm S.E.M. of 8 animals per group. Statistical analysis was carried out using the one way analysis of variance (ANOVA) followed by Student Newman Keul's post hoc test for multiple comparisons. $P$-values less than $0.05(\mathrm{P}<0.05)$ were considered as indicative of statistical significance.

\section{RESULTS}

\section{PHYTOCHEMICAL ANALYSIS}

The phytochemical analysis of BSLE revealed the presence of flavones, flavonols, flavanones, xanthones and hydrolizable tannins. The amounts of phenolic compounds present in the extract were: total phenols $0.37 \mathrm{mg} / \mathrm{g}$ and flavonoids $0.17 \mathrm{mg} / \mathrm{g}$. For the HPLC analysis of ethanol extract of $B$. sericea (Fig. 2), rutin, isoquercitrin, kaempferol 3-O-rutinoside and quercetin were used as standards. The structural characteristics of each identified peak in Fig. 2 was determined by comparing its correspondent UV spectrum with those UV spectra available at the HPLC computer library. For dried leaves, the percentage concentration for each flavonoid was evaluated in relation to a quercetin standard curve as: isoquercitrin $0.13 \%$, quercetin $0.003 \%$, rutin $0.007 \%$ and kaempferol 3-O-ritinoside $0.07 \%$.

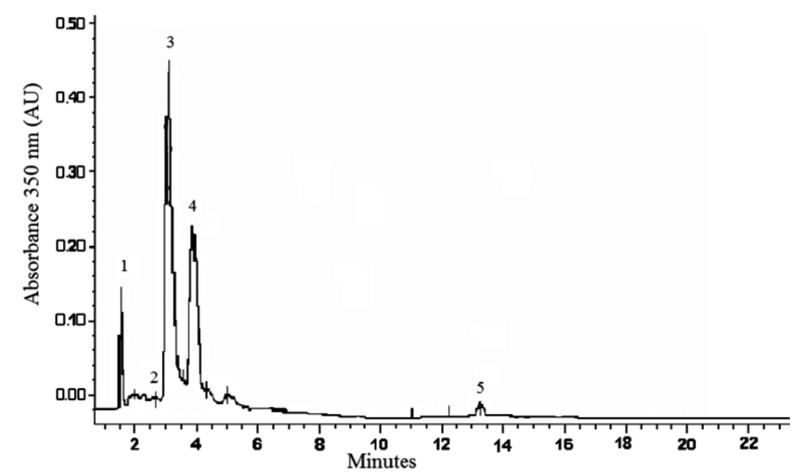

Fig. 2- HPLC Chromatogram of the ethanolic extract of $B$. sericea. Column: Waters C18 (150 x 3.9 mm, $4 \mu \mathrm{m}$; eluent: water /ACN / fosforic acid / 80:20), Flow-rate: $1 \mathrm{ml} / \mathrm{min}, 20 \mu \mathrm{l}$, Temperature $21^{\circ} \mathrm{C}$. Detection: $350 \mathrm{~nm} .1$. unidentified, 2. Rutin, 3. Isoquercitrin, 4. Kaempferol 3-O-rutinoside, 5. Quercetin.

\section{EFFECT OF BSLE ON GASTRIC DAMAGE}

INDUCED BY ETHANOL

The oral administration of BSLE (125, 250 and $500 \mathrm{mg} / \mathrm{kg}$ ) exhibited a protective effect against ethanol-induced gastric lesions in comparison to the vehicle group. The inhibition percentages for the respective doses employed were 53.2, 84.9 and $87.6 \%$. NAC, which was the positive control included for the study, also offered a significant protection (Table I). 
Table I

Effect of $B$. sericea extract (BSLE) on gastric damage induced by absolute ethanol in mice.

\begin{tabular}{lcc}
\hline Treatment & Dose & Ethanol lesion area $\left(\mathrm{mm}^{2}\right)$ \\
\hline Vehicle & - & $21.8 \pm 0.4$ \\
BSLE & $125 \mathrm{mg} / \mathrm{kg}$ & $10.4 \pm 1.0^{* * *}$ \\
& $500 \mathrm{mg} / \mathrm{kg}$ & $3.3 \pm 0.6^{* * *}$ \\
& $250 \mathrm{mg} / \mathrm{kg}$ & $2.7 \pm 0.5^{* * *}$ \\
NAC & $150 \mathrm{mg} / \mathrm{kg}$ & $3.0 \pm 0.5^{* * *}$ \\
\hline
\end{tabular}

Data are mean \pm S.E.M of 8 animals in each group.*** $\mathrm{p}<0.001$ vs. Vehicle (ANOVA followed by Student Newman Keul's test).

\section{EFFECT OF BSLE ON ANTI-OXIDANT PARAMETERS}

The animals that received only ethanol showed a significant decrease in gastric catalase (CAT), superoxide dismutase (SOD) and NP-SH levels, and a significant TBARS level increase (Table II). Animals pretreated with BSLE $(250 \mathrm{mg} / \mathrm{kg})$ effectively decreased TBARS levels almost to a similar extent to NAC $(150 \mathrm{mg} / \mathrm{kg})$. Animals treated with BSLE showed a significant enhanced activity of the antioxidant enzyme SOD. The NP$\mathrm{SH}$ level in gastric mucosa of normal control mice $(280.1 \pm 12.7 \mu \mathrm{g} / \mathrm{g})$ was significantly lowered by the ethanol treatment $(102.3 \pm 10.4 \mu \mathrm{g} / \mathrm{g})$ (Table II). Both BSLE and NAC inhibited the NPSH depletion caused by ethanol $(229.1 \pm 9.9$ and $239.5 \pm 6.5 \mu \mathrm{g} / \mathrm{g}$, respectively regarding the doses employed).

Table II

Effects of B. sericea leaf extract on the contents of CAT, SOD and MDA on gastric damage induced by absolute ethanol in mice.

\begin{tabular}{lllll}
\hline Treatment & $\begin{array}{l}\text { CAT } \\
(\mathrm{U} / \mu \mathrm{g} \text { protein })\end{array}$ & $\begin{array}{l}\text { SOD } \\
(\mathrm{U} / \mu \mathrm{g} \text { protein })\end{array}$ & $\begin{array}{l}\text { TBARS } \\
(\mathrm{U} / \mu \mathrm{\mu g} \text { protein })\end{array}$ & $\begin{array}{l}\text { NP-SH } \\
(\mathrm{U} / \mu \mathrm{g} \text { protein })\end{array}$ \\
\hline No lesion & $4.96 \pm 1.01$ & $1.04 \pm 0.28$ & $54.68 \pm 6.9$ & $280.1 \pm 12.7$ \\
Vehicle & $2.66 \pm 0.24^{\mathrm{a}}$ & $0.69 \pm 0.26^{\mathrm{a}}$ & $86.63 \pm 17.3^{\mathrm{a}}$ & $102.3 \pm 10.4^{\mathrm{a}}$ \\
$\begin{array}{l}\mathrm{BSLE} \\
(250 \mathrm{mg} / \mathrm{kg})\end{array}$ & $3.50 \pm 0.27$ & $1.08 \pm 0.15^{\mathrm{b}}$ & $67.76 \pm 7.5^{\mathrm{b}}$ & $229.1 \pm 9.9^{\mathrm{b}}$ \\
$\begin{array}{l}\mathrm{NAC} \\
(150 \mathrm{mg} / \mathrm{kg})\end{array}$ & $2.78 \pm 0.41$ & $1.08 \pm 0.12^{\mathrm{b}}$ & $62.1 \pm 6.96^{\mathrm{b}}$ & $239.5 \pm 6.5^{\mathrm{b}}$ \\
\hline
\end{tabular}

Data are mean \pm S.E.M of 8 animals in each group. a $\mathrm{p}<0.01$ vs. No lesion; $\mathrm{b} p<0.01$ vs. Vehicle (ANOVA followed by Student Newman Keul's test).

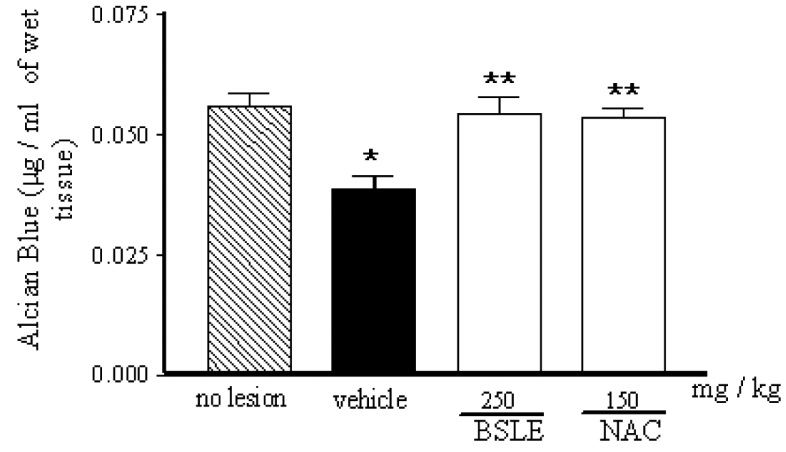

Fig. 3 - Effect of the B. sericea extract (BSLE) treatment on the amount of mucus after induction of gastric lesions by ethanol in mice. The results are expressed as mean \pm S.E.M. $* \mathrm{p}<0.01$ vs. no lesion; $* *$ p $<0.01$ vs. vehicle (ANOVA followed by Student Newman Keul's test).

\section{EFFECT OF BSLE ON GASTRIC MUCUS}

The amount of gastric mucus was significantly $(\mathrm{p}<0.01)$ less in the gastric tissues collected from ethanol-treated animals, as compared to non-damaged tissues from the control. The pretreatment of animals with BSLE greatly enhanced the gastric mucus when compared to animals with ethanol injury (Fig. 3).

EFFECT OF TRPV1 AND $\mathrm{K}^{+}$ATP- CHANNELS AND THE ROLE OF NitRIC OXIDE ON THE GASTROPROTECTIVE EFFECT OF BSLE

In mice pretreated with vanilloid antagonist capsazepine, the gastroprotective effect of BSLE $(250 \mathrm{mg} / \mathrm{kg})$ and capsaicin $(0.3 \mathrm{mg} / \mathrm{kg}$, v.o.) was significantly reduced (Fig. 4A). These data indicate that the gastroprotective effect of BSLE is mediated by the activation of capsaicin-sensitive primary afferents. L-NAME $(20 \mathrm{mg} / \mathrm{kg})$ pretreatment significantly blocked the gastroprotection produced by BSLE and L-arginine (400 $\mathrm{mg} / \mathrm{kg}$, i.p.), suggesting the participation of NO (Fig. 4B) on the BSLE gastroprotection. The pretreatment with $\mathrm{K}+\mathrm{ATP}$ channel blocker, glibenclamide $(5 \mathrm{mg} / \mathrm{kg}$, i.p.), also significantly reduced the gastroprotection produced by BSLE and diazoxide ( $3 \mathrm{mg} / \mathrm{kg}$, i.p.) (Fig. 4C), which indicates a role for $\mathrm{K}^{+}{ }_{\text {ATP }}$ channels in the gastroprotection. 


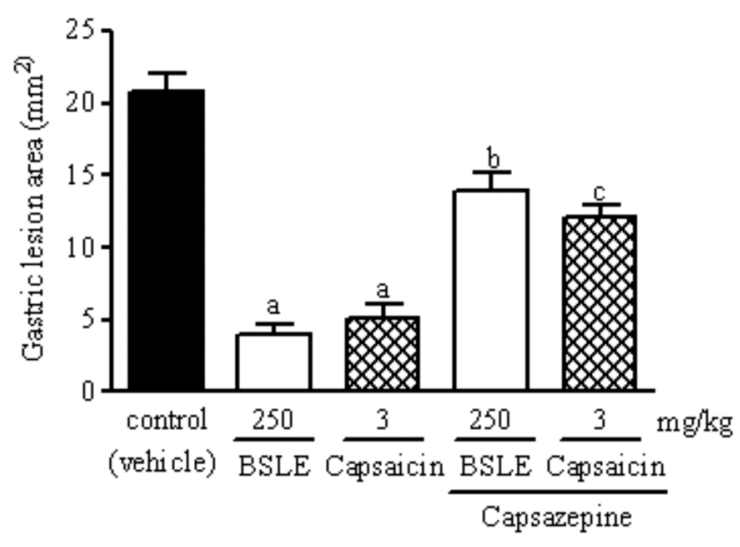

(A)

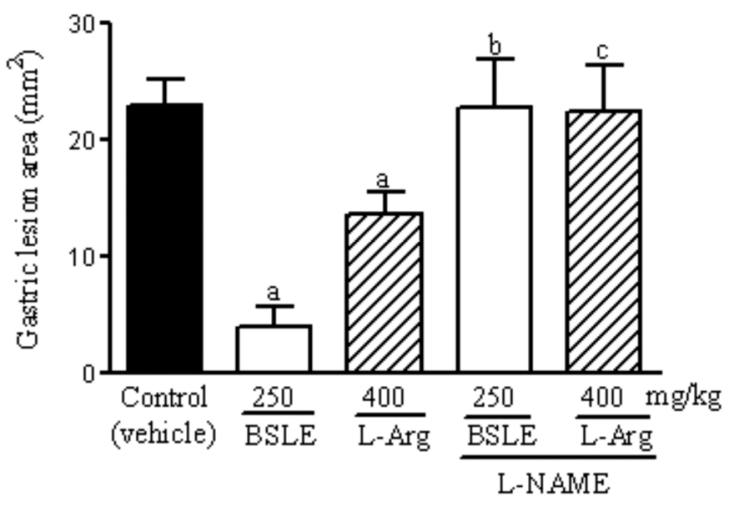

(B)

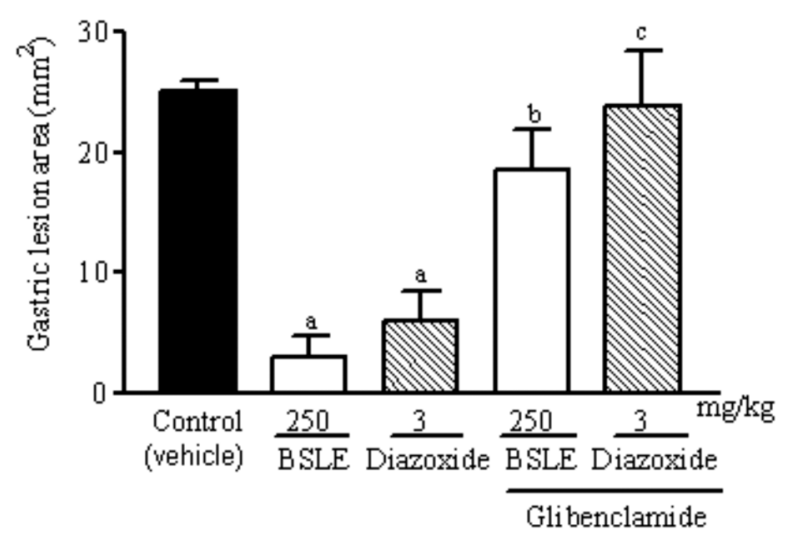

(C)

Fig. 4 - (A) The involvement of TRPV1 channel in the gastroprotective effect of BSLE against ethanol that induced gastric damage in mice - (B) The involvement of nitric oxide in the gastroprotective effect of BSLE against ethanol that induced gastric damage in mice - (C) The role of K+ATP channels in the gastroprotective effect of BSLE against ethanol-induced gastric damage in mice. The results are expressed as mean \pm S.E.M. ${ }^{a} \mathrm{p}<0.001$ vs vehicle; ${ }^{\mathrm{b}} \mathrm{p}<0.001$ vs BSLE alone; ${ }^{c} \mathrm{p}<0.001$ vs L-arginine (L-arg) or diazoxide alone or capsaicin alone (ANOVA followed by Student Newman Keul's test).

\section{DISCUSSION}

The phytochemical analysis of BSLE indicated the presence of flavonoids and tannins, and the HPLC analysis confirmed the presence of rutin (quercetin 3-O-rutinoside), isoquercitrin (quercetin 3-O-glucoside), kaempferol 3-O-rutinoside and quercetin as the main secondary metabolites. Several flavonoids and their structurally related compounds have been shown to inhibit lipid peroxidation (Katsube et al. 2006).

The results of this study show that BSLE at doses of 125,250 and $500 \mathrm{mg} / \mathrm{kg}$ affords a pronounced gastroprotection against ethanol that induced lesions, which is probably due to the presence of strong antioxidant flavonoids in the extract. The gastroprotective and antioxidant effects of quercetin and rutin are well known (La Casa et al. 2000, De la Lastra et al. 1994), and there are many studies showing the antiulcerogenic properties of flavonoids (Gonzalez and Di Stasi 2002). The role of reactive oxygen species in the pathogenesis of acute ethanol that induced gastric mucosal lesions and the effects of quercetin have been evaluated in a few studies. It has been confirmed that the quercetin treatment significantly inhibits the gastric erosions induced by ethanol (Gracioso et al. 2002). Galati et al. (2003) have also stated that there is a correlation between the antioxidant and the antiulcer activities of flavonoids.

The oxidative stress and impaired prostaglandin synthesis contribute to gastric mucosal damage in experimental models of gastric lesions induced by ethanol (Chattopadhyay et al. 2006). The administration of BSLE $(250 \mathrm{mg} / \mathrm{kg})$ to animals increased the levels of gastric NP-SH (GSH) and the amount of mucus. Baggio et al. (2007) demonstrated that the oral administration of the Maytenus ilicifoli leaf extract that is rich in flavonoids can increase the mucus production in the ethanol model of gastric damage in mice, which is in agreement with our data. Both gastric mucus and glutathione serve as protective agents against mucosal injury (Chen et al. 2005, Cnubben et al. 2001). 
The plant-derived natural antioxidants are extremely useful to combat the oxidative stress, and antioxidant enzymes such as superoxide dismutase (SOD) and catalase (CAT), in a preventive way, act as the first line of defense against the reactive oxygen species (Repetto and LLesuy 2002). Acute treatment with ethanol promotes oxidative stress, enhancing consequently the lipid peroxidation and malonaldehyde formation (Peskar et al. 2002). The present study clearly shows that BSLE inhibits lipid peroxidation and lowers TBARS formation, which indicates a cytoprotective function.

Several studies have reported that NO is involved in the preservation of mucous membrane integrity in experimental models of gastric ulceration (Ancha et al. 2003, Cho 2001, Kwiecień et al. 2002). In this study, L-arginine (400 mg/kg) and BSLE $(250 \mathrm{mg} / \mathrm{kg})$ induced gastroprotection, but it was reversed by L-NAME, a non-selective NOS inhibitor, suggesting that the gastroprotective effect of BSLE is mediated, in part, by NO.

It is known that potassium channels are involved in a variety of stomach physiological functions and that gastroprotection can be inhibited by several agents such as indomethacin, $\mathrm{K}+\mathrm{ATP}$ blockers and glibenclamide (Peskar et al. 2002). Glibenclamide, $\mathrm{a} \mathrm{K}^{+}{ }_{\text {ATP }}$ channels blocker, significantly antagonized the protective effect of BSLE and diazoxide. These results support the hypothesis that the $\mathrm{K}^{+}$ATP channel opening is involved in the gastroprotective activity of BSLE. Since this protection is also sensitive to indomethacin, it is suggested that endogen prostaglandins activate the $\mathrm{K}^{+}$ATP channels and that this mechanism is responsible, in part, for the BSLE gastroprotective action (Campos et al. 2008). The results of this study indicate that BSLE has a cytoprotective role in the gastroprotection against gastric damage induced by ethanol, which is presumably mediated, in part, by the nitric oxide release and $\mathrm{K}^{+}{ }_{\text {ATP }}$ channel opening.

The extract does not seem to be toxic as consecutive daily oral administrations of BSLE (500 or $1000 \mathrm{mg} / \mathrm{kg}$ ) over a period of 7 days to mice did not produce any signs of overt toxicity. In conclusion, these findings suggest that the ethanolic extract of $B$. sericea is a safe gastroprotectant to obliterate gastric dysfunction associated with pathologies.

\section{ACKNOWLEDGMENTS}

The authors thank Fundação Cearence de Apoio ao Desenvolvimento Científico e Tecnológico (FUNCAP) and Conselho Nacional de Desenvolvimento Científico e Tecnológico (CNPq, Brazil) for financial support.

\section{RESUMO}

Folhas de Byrsonima sericea são amplamente utilizadas na medicina popular no Brasil no tratamento de distúrbios gástricos. Este estudo investigou os constituintes químicos do extrato etanólico das folhas de $B$. sericea (BSLE) e sua atividade gastroprotetora com seus possíveis mecanismos de ação utilizando o modelo de lesão gástrica induzida por etanol em camundongos. A análise fitoquímica foi realizada para identificar os componentes ativos presentes no extrato e análise por HPLC foi realizada para a identificação de flavonóides. A administração de BSLE (v.o.) nas doses de $125,250,500 \mathrm{mg} / \mathrm{kg}$, v.o. atenuou significativamente as lesões gástricas induzidas por etanol em 53,2, 84,9 e $87,6 \%$ respectivamente. BSLE $(250 \mathrm{mg} / \mathrm{kg})$ preveniu a depleção do muco gástrico, de grupamentos sulfidrílicos não-protéicos (GSH), das atividades da SOD e da CAT assim como o aumento de malonaldeído promovido pelo etanol. Além disso, o efeito gastroprotetor do BSLE foi significantemente reduzido pelos pré-tratamentos com capsazepina(i.p.), L-NAME(i.p.) ou glibenclamida(i.p.), respectivamente bloqueadores/inibidores de receptores TRPV1, NO sintase e canais de K+ATP. A investigação fitoquímica revelou a presença de flavonoides como rutina, isoquercitrina, 3-O-rutinosideo-canferol e quercetina que são conhecidas por suas propriedades antioxidantes e gastropotetoras. O estudo demonstrou 
que BSLE proporciona ação gastroprotetora através de vários mecanismos que podem ser úteis no tratamento de patologias associadas a disfunções gástricas.

Palavras-chave: Antioxidante, Byrsonima sericea, Flavonoides, Gastroproteção, Mecanismos de ação.

\section{REFERENCES}

Ancha H, OJeas H, Tedesco D, Ward A AND Harty RF. 2003. Somatostatin-induced gastric protection against ethanol: involvement of nitric oxide and effects on gastric mucosal blood flow. Regul Peptides 110: 107-113.

Arrieta J, Benitez J, Flores E, CAstillo C AND NAVARRETE A. 2003. Purification of gastroprotective triterpenoids from the stem bark of Amphipterygium adstringens; role of prostaglandins, sulfhydryls, nitric oxide and capsaicin-sensitive neurons. Planta Med 69: 905-909.

Baggio CH, Freitas CS, Otofuji GM, Cipriani T, Souza LM, SAssaki GL, IACOMIni M, Marques MC AND MESIA-VELA S. 2007. Flavonoid-rich fraction of Maytenus ilicifolia Mart. ex. Reiss protects the gastric mucosa of rodents through inhibition of both $\mathrm{H}^{+}, \mathrm{K}^{+}$-ATPase activity and formation of nitric oxide. J Ethnopharmacol 113: 433-440.

BeAuchamp C AND Fridovich I. 1971. Superoxide dismutase: improved assays and an assay applicable to acrylamide gels. Anal Biochem 44: 276-287.

Boscolo OH, MendonçA-Filho RFW, Menezes FS AND SenNA-VALLE L. 2007. Potencial antioxidante de algumas plantas de restingas citadas como medicinais. Rev Bras Plant Med 9: 8-12.

BRADFORD MM. 1976. A rapid and sensitive method for the quantitation of microgram quantities of protein utilizing the principle of protein-dye binding. Anal Biochem 72: 248-254.

CAMPoS DA, DE LIMA AF, RibeIRo RS, SilveIRA ER, Pessoa OD, RaO VS and Santos FA. 2008. Gastroprotective effect of a flavone from Lonchocarpus araripensis Benth. (Leguminosae) and the possible mechanism. J Pharm Pharmacol 60: 391-397.

Cardoso CR, DE Syllos-Cólus IM, Bernardi CC, SANNOMIYA M, VILEGAS W AND VARANDA EA. 2006. Mutagenic activity promoted by amentoflavone and methanolic extract of Byrsonima crassa Niedenzu. Toxicology 225: 55-63.

CHATTOPADHYAY I, BANDYOPADHYAY U, BISWAS $\mathrm{K}$, MAITY P AND BANERJEE PK. 2006. Indomethacin inactivates gastric peroxidase to induce reactive-oxygenmediated gastric mucosal injury and curcumin protects it by preventing peroxidase inactivation and scavenging reactive oxygen. Free Radic Biol Med 40: 1397-1408.
Chen SH, Liang YC, ChaO JC, Tsai TH, Chang CC, WANG CC AND PAN S. 2005. Protective effects of Ginkgo biloba extract on the ethanol-induced gastric ulcer in rats. World J Gastroenterol 11: 3746-3750.

CHO CH. 2001. Current roles of oxide nitric in gastrointestinal disorders. J Physiol Paris 95: 253-256.

CNubBen NHP, RietJens IMCM, Wortelboer H, VAN ZANDEN JPJ AND VAN BLADEREN PJ. 2001. The interplay of glutathione-related processes in antioxidant defense. Environment Toxicol Pharmacol 10: 141-152.

CORNE SJ, MORRISEY SM AND WOODS RJ. 1974. A method for the quantitative estimation of gastric barrier mucus. J Physiol 224: 116-117.

De La Lastra CA, Martin MJ and Motilva V. 1994. Antiulcer and Gastroprotective effects of Quercetin: A Gross and Histologic Study. Pharmacology 48: 56-62.

Galati EM, Mondello MR, Giuffrida D, Dugo G, Miceli N, Pergolizzi S and taviano MF. 2003. Chemical characterization and biological effects of Sicilian Opuntia ficus indica (L.) mill. Fruit juice: antioxidant and antiulcerogenic activity. J Agric and Food Chem 51: 4903-4908.

GONZALEZ FG AND Di STASI LC. 2002. Anti-ulcerogenic and analgesic activities of the leaves of Wilbrandia ebracteata in mice. Phytomedicine 9: 125-134.

Gracioso JS, Vilegas W, Hiruma-Lima CA AND SouzA BRITO AR. 2002. Effects of tea from Turnera ulmifolia L. on mouse gastric mucosa support the Turneraceae as a new source of antiulcerogenic drugs. Biol Pharm Bull 25: 487-491.

KATSUBE T, IMAWAKA N, KaWANO Y, YAMAZAKI Y, SHIWAKU K AND YAMANEY. 2006. Antioxidant flavonol glycosides in mulberry (Morus alba) leaves isolated based on LDL antioxidant activity. Food Chem 97: 25-31.

KWIECIEŃ S, BRZOZOWSKI T, KONTUREK PCH AND KONTUREK SJ. 2002. The role of reactive oxygen species in action of nitric oxide-donors on stress-induced gastric mucosal lesions. J Physiol Pharmacol 53: 761-73.

la Casa C, Villegas I, de La Lastra CA, Motilva V and MARTín CALERO MJ. 2000. Evidence for protective and antioxidant properties of rutin, a natural flavone, against ethanol induced gastric lesions. J Ethnopharmacol 71: 45-53.

LIMA ZP ET AL. 2008. Byrsonima fagifolia: An integrative study to validate the gastroprotective, healing, antidiarrheal, antimicrobial and mutagenic action. J Ethnopharmacol 120: 149-160.

Lira LM, DOS SANTOS FV, SANNOMIYA M, Rodrigues CM, VILEGAS W AND VARANDA EA. 2008. Modulatory effect of Byrsonima basiloba extracts on the mutagenicity of certain direct and indirect-acting mutagens in Salmonella typhimurium assays. J Med Food 11: 111-119. 
MAEHLY AC AND ChANCE B. 1954. The assay catalases and peroxidases. Methods Biochem Anal 1: 357-424.

MARTÍNEZ-VÁZquez M, GONZÁLES-ESQUINCA AR, CAZARES LUNA L, MORENO GUTIÉRREZ MN AND GARCÍA-ARGÁEZ HBK. 1999. Antimicrobial activity of Byrsonima crassifolia (L.) J Ethnopharmacol 66: 79-82.

MATOS FJA. 1997. Introdução à Fitoquímica Experimental, $2^{\text {nd }}$ ed., Fortaleza: Edições UFC, 141 p.

Mendes CC, CRUZ FG, DAVID JM, NASCIMENTO IP AND DAVID JP. 1999. Triterpenes esterified with fatty acid and triterpene acids isolated from Byrsonima microphylla. Quim Nova 22: 185-188.

OHKaWA H, OHISHI N And Yagi K. 1979. Assay for lipid peroxidation in animal tissue by thiobarbituric acid reaction. Anal Biochem 95: 351-358.

Peskar BM, Ehrlich K AND Peskar BA. 2002. Role of ATP-sensitive potassium channels in prostaglandin mediated gastroprotection in the rat. J Pharmacol Exp Ther 301: 969-974
REPETTO MG AND LLESUY SF. 2002. Antioxidant properties of natural compounds used in popular medicine for gastric ulcers. Braz J Med Biol Res 35: 523- 534.

Robert A, Nezamis JE, Lancaster C And Hanchar AJ. 1979. Cytoprotection by prostaglandins in rats. Prevention of gastric necrosis produced by alcohol, $\mathrm{HCl}, \mathrm{NaOH}$, hypertonic $\mathrm{NaCl}$, and thermal injury. Gastroenterology 77: 433-443.

SANNOMIYA M, CARdoso CR, FigueIREdo ME, Rodrigues CM, dos SAntos LC, Dos SAntos FV, SERPEloni JM, Cólus IM, Vilegas W and Varanda EA. 2007. Mutagenic evaluation and chemical investigation of Byrsonima intermedia A. Juss. leaf extracts. J Ethnopharmacol 112: 319-326.

SEDLAK J AND LINDSAY RH. 1968. Estimation of total, protein-bound, and nonprotein sulfhydryl groups in tissue with Ellman's reagent. Anal Biochem 25: 192-195. 